\title{
RE-INVENTED WATER-RELATED SPACES IN THE BUILT ENVIRONMENT
}

DOI: 10.18485/arh_pt.2020.7.ch2

\section{_ Gábor Heckenast}

Doctoral student, Breuer Marcell Doctoral School of Architecture,

Faculty of Engineering and Information Technology, University of Pécs,

Boszorkány u. 2, H-7624 Pécs, Hungary, gabor.heckenast@gmail.com

\section{_ Marcel Ferencz Habil, DLA}

Full professor, Ph.D, Ybl Miklós Faculty of Architecture and Civil Engineering, Szent István University, Thököly út 74., H-1146 Budapest, Hungary, ferencz.marcel.istvan@ybl.szie.hu

\section{András Tibor Kertész \\ Full professor, Ph.D, Breuer Marcell Doctoral School of Architecture, Faculty of Engineering and Information Technology University of Pécs, Boszorkány u. 2, H-7624 Pécs, Hungary, kertesz.andras@mik.pte.hu}

\begin{abstract}
The focus of this paper is the environmental awareness used for the water-related built environment - both on a building and urban scale. Water as natural element plays an enormous role in shaping our natural and built environments, thus it has also radically formed architectural thinking on creating space throughout the ages worldwide. Observing evolving building technology gives us an overview, which allows us to recognize a pattern in architectural thinking on creating water-related spaces, even if it was built for residential, commercial, recreational or representational purposes. A deeper understanding of the fundamental relationship between nature, water and settlements, helps reduce the disadvantageous impact of human activity on nature, which has been growing over time. Sustainable design methods need to be (re)invented to meet new and changing conditions in settlements, for living in harmony with nature - as it once was. Nowadays, new paths and solutions have opened up at an accelerating pace, thanks to the research and development in technology, which also provides an opportunity for a continuous dialogue between nature and architecture. Contemporary architecture tries to reshape its way of thinking on nature, based on the idea of re-finding a harmonious symbiosis with the power of science and technology to provide sustainable alternatives for the future.
\end{abstract}

KEYWORDS _ water, urban planning, sustainability, technology, design methods

\section{INTRODUCTION}

Water has always played a central role in human history. When the first settlements were formed, the proximity of water was a primary consideration for basic needs, strategic and commercial purposes. With the development of technology, the appearance of water in architecture has become much more diverse with new solutions, which only existed in the world of imagination before. Thanks to new solutions, unprecedented opportunities are opening up in architecture, revolutionizing the relationship between the built environment and water. 


\section{THE ROLE OF WATER AND TECHNOLOGY IN ARCHITECTURE}

Water is one of the most versatile natural elements, so it appears in architecture in various ways depending on the different techniques: building material (e.g. igloo, ice hotel), processing method (water jet cutting machine), water-related facades (indirectly: algae, green facades or directly: fog, programmed waterfall facades). However, in architecture, water not only influences the physical space (such as swimming pools), but it can also determine the architectural thinking by its physical or behavioural nature (e.g. fluid architecture), whether inside or outside the building.

In the built environment the water surface can be natural or artificial, which fundamentally determines the construction technology and influences the architectural design as well.

With the development of new ideas and technology, water can even symbolically appear on facades: it can be parametric, biomorphic or kinetic - as in the case of Ned Kahn's facade installation, which imitates a vertical water surface with small swinging metal keys.

As water appears in our environment with an increased presence, the initial instinctive way of building has been replaced by a scientific approach in construction: creating a much closer relationship by reducing the physical distance between the water and architectural spaces. This close relationship makes the well thought out choice of the right technology in architecture essential in the future (Figure 1).

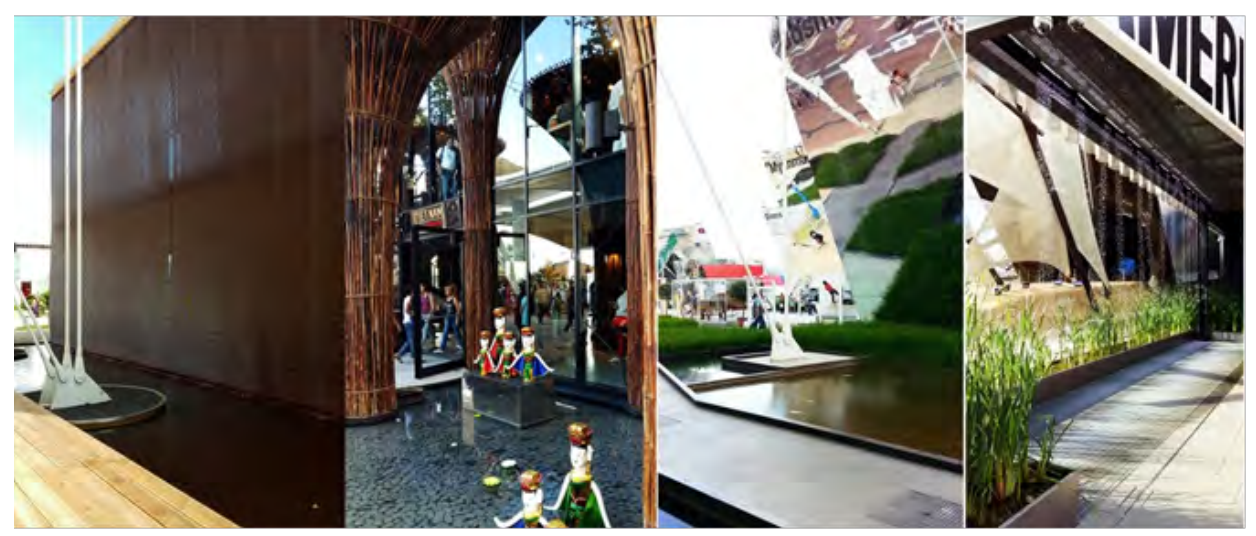

_Figure 1: Water features - Milan Expo, 2015 (source: G. Heckenast)

Knowing the physical properties of water opens up new opportunities in architectural applications (such as surface tension - tension structures, water behaviour - water analogues in architecture, light transmission - underwater architecture), which greatly determine the technology used as well. Over time, as environmental conditions have changed with the earth's climate, water levels have also risen. Architecture must also respond to the changed circumstances and climate change with the help of modern technology. New architectural and urban design approaches are emerging that could provide a lifestyle in harmony with the environment (amphibious housing, green cities, solar power, wind farm).

In the case of water-related architectural designs, form is not the principal, rather the idea itself, which responds to needs in a creative way, offering a new opportunity and solution for the function. Architecture is currently experiencing a period of transition, accompanied by unprecedented technological advances and ever-changing demands. Dynamic reflection in contemporary architecture requires an environmentally conscious approach that responds to new demands and complex effects. 


\section{THE HISTORY OF WATER RELATED TECHNOLOGY DEVELOPMENT}

Water management is as old as history, water supply is essential for life and for cities to function. In most cases stagnant waters cause hygienic problems, so the quality of life has been greatly increased by the water cycle and the establishment of the water network (e.g. Mesopotamia, Egypt - irrigation system).

In Prehistoric times, primitive reservoirs and riverbed control appeared, which were the first elements of water management. In Ancient times, plumbing networks and canals were created. Without them, it would not have been possible to establish baths, toilets and irrigation systems. The Middle Ages provided new solutions besides the old ones, along with defence structures (e.g. castle ditches), such as giving new living space to the town's inhabitants with the appearance of residential bridges over the rivers.

Since the Renaissance, complex systems have come to the forefront of technological advances: underground cisterns, urban sewerage networks, buildings with utilities, spring houses and water castles and other buildings on water. For example, the Paris Opera House was built over a natural lake thanks to advanced technology. The construction of waterways and canals - with along fortifications - was one of the largest constructions in Europe, providing an essential basis for transportation and water management.

Until the 18th century in Europe technology was water and wood based. Most of the engineering work was related to water, which was a branch of architecture, called "architecture hydraulique". Landscape architecture was also part of engineering education. (for example, Versailles waterworks in the garden with hydraulic engines; Pontcysyllte navigable aquaduct, England, 1805). At that time science started to deal with hydrodynamic regularities and introduced the fluid models that also influenced the Haussmannian city.

From the Middle Ages to the end of the 18th century In Western Europe, water mills were one of the major sources of energy for industry and agriculture, emphasizing the role of the geographical position in the development.

From the 19th century, the role of water changed with the Industrial Revolution, when coal and steam were the source of energy and railway was the new transport alternative, which transformed fundamentally the image of cities. As a consequence of the Industrial Revolution, cities have undergone an unprecedented transformation: large-scale waterbed control, waterbed filling, steel bridges, steam turbine houses, and new neighborhoods were created.

Even though the steam engines of the Industrial Revolution are outdated, two-thirds of the world's energy consumption is still generated by turbines. Waterfront urban areas are becoming more valuable, displacing former water-based industrial activity.

With the era of modern architecture, new concepts have emerged regarding the role of water in architecture, the use of water has become more subtle and flowing spaces have appeared.

In contemporary architecture, water has become a medium while still providing basic necessities (water analogy, tool for illusion, e.g. Diller Scofidio + Renfro: Blur, Switzerland). Along with new environmentally conscious technologies, floating buildings and neighborhoods, underwater buildings (e.g. Snohetta: Underwater restaurant), landscaped bridges start to transform our image of the city. In the 21 st and 22nd centuries, the relationship between water and architecture will be a key issue to ensure sustainable development. In the future, this relationship will be taken to a whole new level and the new technology will make it possible to build floating and underwater cities (e.g. Vincent Callebaut: Citypad - Floating City; Arup Biometrics: Ocean City). The desire of building on water has a long history, for example Uros Indians already built a floating reed island village on the Lake Titicaca a long time ago. 


\section{WATER, TECHNOLOGY AND BUILDINGS}

One of the most important elements of architecture is the idea itself, so architects are constantly looking for new solutions to bring them to life. This is where the technology comes in, which offers several solutions to the upcoming problems. Even more, technology not only provides solutions, but can also help the creative process itself. There are many examples of this close relationship, not to mention the epoch-making discoveries.

In most cases, nature provides the best inspiration for solving a problem. The animals' extraordinary adaptation has provided many architectural solutions many times: beavers - dyke, nests - thatch, use of leaves - shelters, bears - caves, spiders - rope structures, bee hive - module system.

As technology advances in water-related architecture, the language of architectural design is transformed, further enriching our diverse built environment. Water greatly influences construction technology: building materials (for igloo), manufacturing technology (water jet CNC), programmed waterfalls, water towers, condensation towers, hydroelectric power plants, atomic energy (heavy water), water facades, waterways, waste water management, that significantly shape our environment.

The built environment is extremely complex, created by not only architecture but also the union of the connecting fields to architecture. A well-functioning building must be settled in its environment with a sort of symbiosis, which can only be achieved with landscape architecture. Not only landscape architecture can be used to place a building in its natural or built environment, but it is also possible to use technology to create closer integrity. It not only has benefits for users but should also have benefits for the environment as well: gardens with cleverly designed water surfaces (pools, fountains, canals), trees like intelligent shades or natural wind canal like air conditioning can create a better microclimate, increasing the comfort of the building without the extra energy input. With a prudent design, conscious use of environmental features and new technological advances, a more environmentally conscious, complex design methodology is being developed.

With climate change, water levels are rising and cities are faced with new challenges now: not only in the aspect of the design of new buildings, but also in protecting the existing built environment and adapting to the new conditions. It facilitates new building types and designs (e.g. footed houses) or major changes in the urban structure (e.g. temporary urban flood areas, buffer zones).

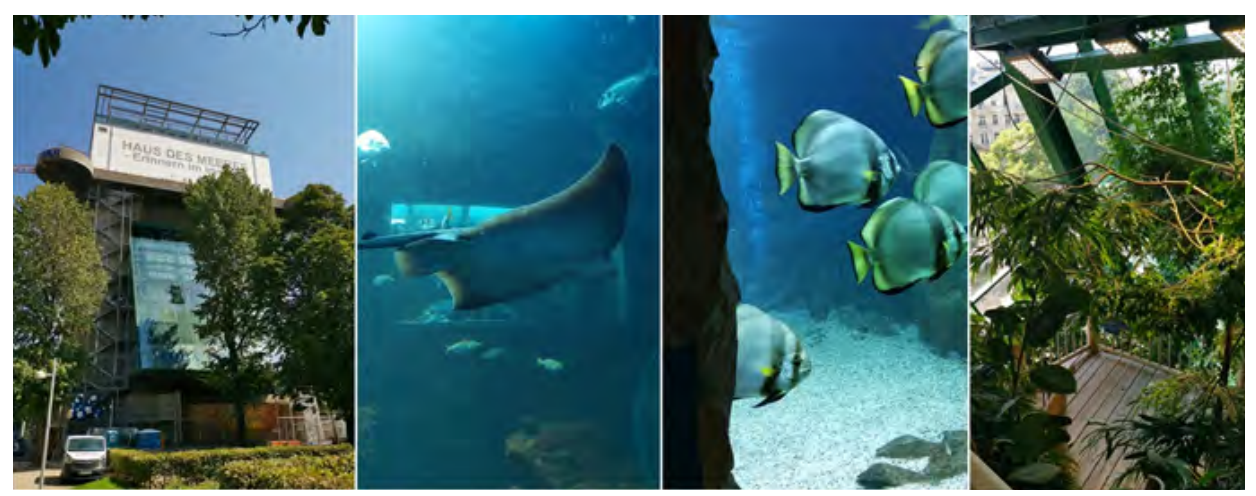

_ Figure 2: Haus des Meeres - House of the Sea (source: G. Heckenast)

\section{Case study: Haus des Meeres (House of the Sea), Vienna, Austria}

After the Second World War, the former almost 50 meter high military facility, was sold by the City of Vienna. The city has allowed the investors to completely convert the tower for a very different function: a zoo, multi-storey-high aquariums and a palm house (Figure 2).

The memento of one of the darkest eras in history has been completely transformed with the help 
of water, both physically and in a mental sense. The remodelling is still going on and the exterior surfaces of the building are also being transformed by green architecture.

\section{WATER, TECHNOLOGY AND URBANISM}

Our buildings and cities require new solutions due to changes in environmental conditions, usage of space and lifestyle changes. The built environment is increasingly affected by technology, transforming older "sculptural" buildings into a sort of machine. These urban machine units or cells, must be integrated in the most responsible way in the environment with the best available technology. By changing attitudes and choosing the right technique, not only can the problem of today be solved, but the problems of the future can be prevented. This approach not only means thinking locally on building-level systems, but using urbanism to implement complex solutions that incorporate the entire built environment with technical and natural scientific aspects, thus interpreting and managing the built and natural environments in the cycle of nature. The built environment and the natural environment seem to form a different system, but the built environment derives essentially from the natural environment, so their reconnection to nature can be done with care while meeting the needs of the age.

The used techniques are greatly influenced by the proximity of the water and the scale of the water, which essentially determines the local architectural character of the area with the natural environment together (e.g. pile houses, boathouse). The relationship between the city and the water is getting closer, new models of the city are being developed, partly using historical structures and technology (e.g. Amsterdam, Venice). A new era can be predicted through technological innovations that would represent water cities (floating buildings, forests, transport hubs).

The green and blue systems of cities need to be reviewed in a complex way to create a viable model for a new sustainable urban fabric. Hybrid solutions should be developed for the historical town structures, which can also provide its residents a sustainable future while preserving the built heritage. For example, as an improvement of microclimatic conditions and to reduce artificial cooling: millions of air conditioning units would not be needed if instead as a part of smart city design it could include green spaces and integration of water surfaces alongside the creation of wind channels too. This methodology, combined with well-chosen technology, will provide the optimum solution for a given problem.

_ Table 1: New concept for cities by city type

\begin{tabular}{|l|l|l|}
\hline Coastal cities & River cities & "Dry cities" \\
\hline settlement on the water & revitalization of coasts & creating new water surfaces \\
\hline energy supply (E) & energy supply (E) & $\begin{array}{l}\text { comprehensive water } \\
\text { management concept }\end{array}$ \\
\hline $\begin{array}{l}\text { environmentally conscious } \\
\text { transport }\end{array}$ & $\begin{array}{l}\text { "moving stage" } \\
\text { - rivers, city attractions } \\
\text { - floating beaches }\end{array}$ & $\begin{array}{l}\text { local economy: } \\
\text { reduction of environmental and } \\
\text { transportation burden }\end{array}$ \\
\hline & fauna oases (biodiversity) & \\
\hline & new levels in the city living space & \\
\hline
\end{tabular}

By applying a new architectural /urban model, the built environment and humanity can be a part of the cycle of nature again, living in harmony with it. This basically means rethinking the appearance of water and green space in cities, from the building scale (e.g. water cycle in building, green facade) to the urban scale (e.g. urban gardens, cooling, transportation). Nature can be integrated into city life by creating biologically active areas, creating an urban ecosystem in symbiosis with nature (e.g. floating islands in the river, floating forests, aquaponics, Japanese kabata water system).

Coastal cities are facing major transformations due to growing space demands and rising water levels (e.g. New York The Dryline, Tokyo Bay, San Francisco Treasure Island, Amsterdam KNSM Island). These transformations not only provide security and growth for the city, but also provide a 
new opportunity to redesign cities, even transform their energy supply (e.g. urban hydropower, wave power, hydroelectric power plant, heat exchangers, new urban management strategies) (Table 1). With the advancement of technology, the shrinking of land areas and the desire for living nearby water, water is becoming more accessible. There are more and more floating water projects: houseboats, office buildings, high-rises, parking lots, museums, airports, parks, forests, hotels, golf courses, gardens, farmland, forts and prison.

Floating cities not only provide new living space for its residents, they are also eco-friendly: they also provide shade in the shallow waters, home for plants and aquatic animals on the bottom of the floating islands.

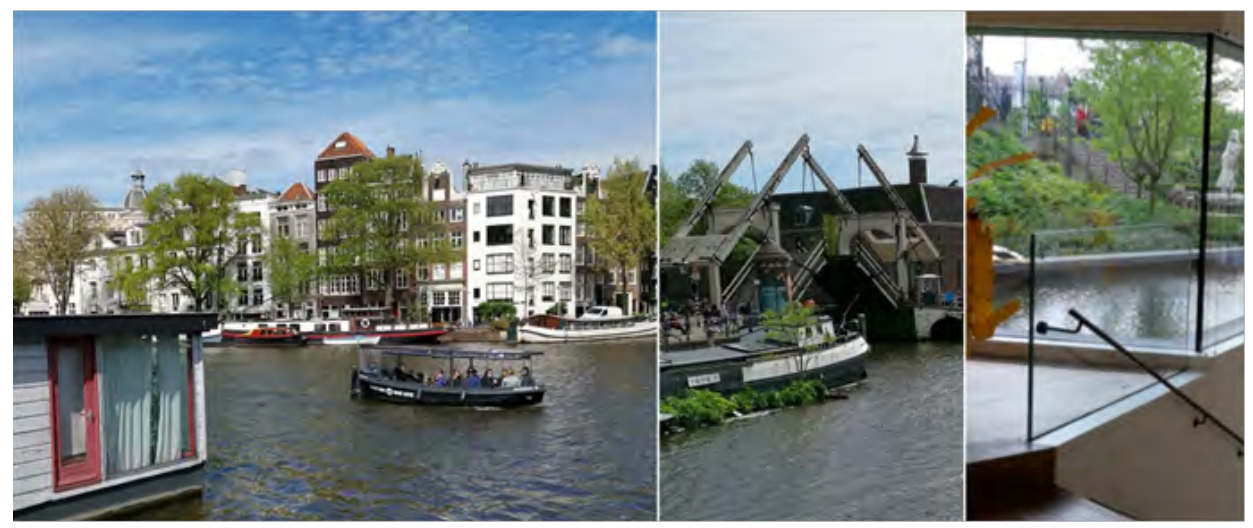

_ Figure 3: Amsterdam, The Netherlands (source: G. Heckenast)

\section{Case study: City of Amsterdam, the Netherlands}

With its rich architectural heritage and connected canal system, Amsterdam is rightly called the Venice of the North. Two meters below sea level, the horseshoe-shaped city center includes $100 \mathrm{~km}$ of canal system, 90 islands and 1,200 bridges (Figure 3).

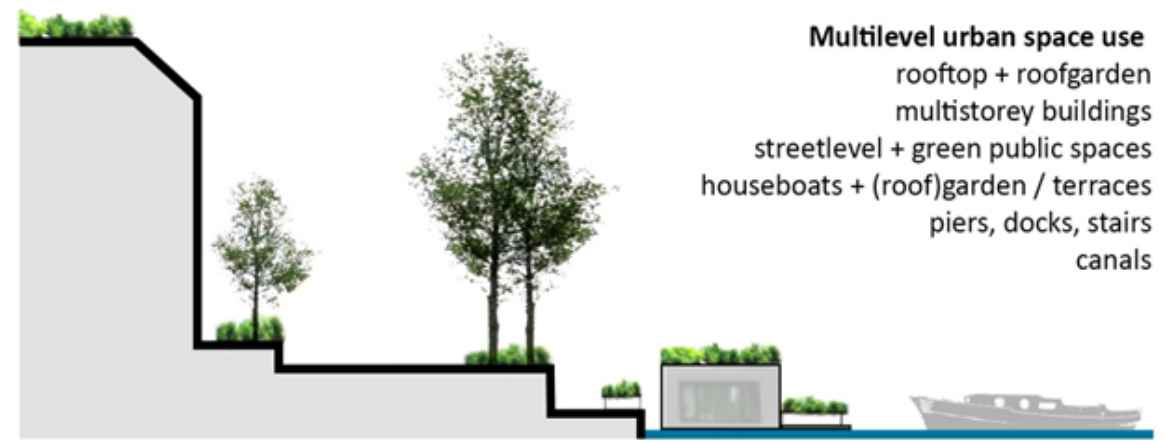

_. Figure 4: Amsterdam multilevel space use (source: G. Heckenast)

Its history dates back to the 12th Century, a small fishing village called "Aemstelredamme". In the 1st Golden Age -17th century- the city became a financial and commercial center (the world's first stock exchange, floating peat island in 1638), and later in the 2nd Golden Age -19th century- during the Industrial Revolution major city developments and new canals were created in the city built on wooden piles. After the Second World War, the city had to be redesigned, creating new suburbs and a metro network. 
In the 21 st Century, the city is constantly being revitalized with more and more green spaces, which is made possible by reducing and redirecting flow of traffic: e.g. moving parking spots, Sail + Ride, underwater tunnels, floating gardens and butterfly parks (Figure 4). New urban development strategies are emerging, such as a 6-storey underwater shopping mall complex right under the historical canal (Zwart \& Jansma Architects: Amfora Amstel).

The architecture of Amsterdam is characterized by a water-oriented and creative attitude, reinterpreting water surfaces and creating new ones based on centuries-old traditions.

\section{CONCLUSIONS}

Water appears in architecture in countless ways, resulting in the most diverse form of design and engineering. Water plays a decisive role not only in architecture, but also in many fields connected to architecture.

Utopian ideas can often be realized through the results of technological advances, redesigning our buildings and cities.

With new environmentally aware technologies, based on the history of technological advancements, we can start a new chapter in the history of architecture, while preserving our existing built environment and leaving behind the old, harmful technical solutions for the sake of a healthy environment. As Earth is a living system, architecture must always be well thought out and adapted with the new opportunities, which are provided by the technology. With the changing environmental conditions, a harmonious complex system can form in association with the natural and built environment, thereby ensuring the liveable conditions and the rights of future generations for a healthy environment.

\section{REFERENCES}

_ Fred Feddes. 2019. A Millennium of Amsterdam. Bussum: Thoth Publisers.

_ Michael Fazio, Marian Moffett, Lawrence Wodehouse. 2013. A World History of Architecture. London: Laurence King Publishing.

_ Zoe Ryan. 2010. Building with water. Basel: Birkhauser.

_ Herbert Girardet. 2008. Cities People Planet. Chichester: John Wiley \& Sons, Ltd.

_ Koen Olthuis, David Keuning. 2010. Float! Amsterdam: Frame.

_ Liat Margolis, Aziza Chaouni. 2015. Out of water. Basel: Birkhauser.

_ Oliver Herwig, Axel Thallemer. 2008. Water - Unity of Art and Science. Germany: Arnoldsche.

_ David Lewis Feldman. 2017. The Water-Sustainable City. Chichester: Edward Elgar

- Publishing. 